\title{
COMPARATIVE STUDY OF METABOLITES AND ANTIMICROBIAL ACTIVITIES OF ESSENTIAL OILS EXTRACTED FROM THREE AMOMUM SUBULATUM CULTIVARS
}

\author{
AFTAB ALAM ${ }^{1 *}$, RITA SINGH MAJUMDAR ${ }^{1}$, PRAVEJ ALAM ${ }^{2}$ \\ ${ }^{1}$ Department of Biotechnology, School of Engineering, Sharda University, Greater Noida, Uttar Pradesh, India. ${ }^{2}$ Department of Biology, \\ College of Science and Humanities, Prince Sattam Bin Abdulaziz University, Al-Kharj, Kingdom of Saudi Arabia. \\ Email: aftab.sharda@gmail.com
}

Received: 24 March 2019, Revised and Accepted: 30 April 2019

ABSTRACT

Objective: In Sikkim (India), Seremna is a highly growing cultivar of Amomum subulatum at lower altitudes. Other popular cultivated varieties are Varlangy and Sawney in the same state but at different altitude. In this study, we evaluate the variation in essential oils, metabolites and antimicrobial activities among A. subulatum selected cultivars.

Methods: The composition of essential oil of Varlangy, Seremna, and Sawney was analyzed using gas chromatography-mass spectrometry and comparative antimicrobial activity of oils was explored using agar well diffusion and agar dilution method.

Results: The Seremna cultivar oil was shown the high content of major constituents (1,8-cineole) in comparison to others. Comparative minimum inhibitory concentrations and minimal bactericidal concentration (MBC) or minimal fungicidal concentration against two Gram-positive (Staphylococcus aureus and Bacillus subtilis), two Gram-negative (Klebsiella pneumoniae and Escherichia coli) bacteria, and two (Candida albicans and Aspergillus niger) fungi were determined. The oil of Seremna showed distinct antibacterial and antifungal activity against all the microorganisms except B. subtilis which showed resistance.

Conclusion: The present findings concluded that the high content of the principal compound accelerates the antimicrobial activity of essential oils. The essential oil of Seremna could be a good antimicrobial agent and recommended in the case of infections.

Keywords: Amomum subulatum, Cultivars, Essential oil, Gas chromatography-mass spectrometry analysis, Antimicrobial activity.

(c) 2019 The Authors. Published by Innovare Academic Sciences Pvt Ltd. This is an open access article under the CC BY license (http://creativecommons. org/licenses/by/4. 0/) DOI: http://dx.doi.org/10.22159/ajpcr.2019.v12i6.33215

\section{INTRODUCTION}

Amomum subulatum (commonly known as large cardamom) is a perennial plant widely cultivated in the sub-Himalayan region of NorthEastern part of India (Sikkim), Northern Uttar Pradesh, Arunachal Pradesh, and Mizoram State belongs to the family Zingiberaceae. The worldwide annual production of large cardamom fruits is $\sim 12 \times 10^{3}$ $\mathrm{mt}$ which is $30 \%$ of the total production coming from Sikkim [1]. The capsules/fruits are the main edible source of this plant and worldwide called as Badi elaichi/Kali elaichi (Hindi), Heel kalan (Urdu), Greater/ Nepal cardamom (English), Cardamom (French), Ts"ao-k"ou (China), and Qakilahe kalan (Persian) [2]. The fruits of $A$. subulatum are mainly used for anti-gonorrhea, kidney stones, respiratory, digestive diseases, and alternative systems of medicine [3]. There are six major cultivars of large cardamom growing in the Sikkim region, i.e., Ramsey, Sawney, Golsey, Varlangy, Bebo, and Seremna [4]. Cultivars such as Seremna, Sawney, and Varlangy are very popular among local growers due to its high productivity and yield [5]. Recent study of bioactive compounds of A. subulatum fruit/seeds has shown the different pharmacological activities such as antioxidants, antiulcer, hypolipidemic agents, antimicrobial activity antidiabetics, and hepatoprotective activity by the different investigators [6-9]. A broad citation on the antimicrobial properties of essential oils has been carried out by several investigators. Essential obtained from various medicinal plants such as Cinnamomum zeylanicum, Eugenia caryophyllata, Rosmarinus officinalis, and Ocimum kilimandscharicum has been reported to possess significant antimicrobial activities and can serve as a powerful tool to reduce the bacterial resistance $[10,11]$. Due to lack of technological errors, the essential oil of the plant or bioactive compound of the particular cultivars (Seremna, Sawney, and Varlangy) has not been tested earlier. Several authors considered, the environmental conditions, e.g., type and composition of the soil (edaphic), geographic and genetic variations are the determinant factors influence the secondary metabolites of the essential oils [12-14]. Keeping the view in mind for cardamom pharmacological properties, we have studied the Seremna, Sawney, and Varlangy essential oils by gas chromatography-mass spectrometry (GCMS) and also observed the effect of their essential oils for antifungal and antibacterial activities collected from Sikkim.

\section{MATERIALS AND METHODS}

\section{Sample collection and extraction of essential oils}

The fruits of three different cultivars of A. subulatum such as Sawney, Seremna, and Varlangy were obtained from Spice Board, ICRI (Indian Cardamom Research Institute), Tadong (Sikkim, India), in the month of November 2016. The hydrodistillation method was used for the extraction of essential oil from three cultivars of Sawney, Seremna, and Varlangy [15]. For each cultivar, $50 \mathrm{~g}$ fine powdered were taken for extraction of oil from each cultivar separately for the time of $4 \mathrm{~h}$. The extracted samples were dried by mixing the sodium sulfate (anhydrous) and stored at $4^{\circ} \mathrm{C}$ for further study. Data were recorded and percentage yields of each cultivar oil were calculated as triplicate.

Chemical characterization: Metabolite identifications through GC-MS

For the comparative qualitative and quantitative study, the essential oils of each cultivar were characterized by GC and GC-MS. GC analysis was carried out using H. P-5890 II apparatus, prepared to splitless injector method using the HP-5M column $(0.52 \mu \mathrm{m}$ film thickness and $25 \mathrm{~m} \times 0.32 \mathrm{~mm}$ ) and FID (flame ionization detector) with $1 \mathrm{ml} / \mathrm{min}$ flow rate of carrier gas $\left(\mathrm{N}_{2}\right)$ and injector temperature $\left(250\right.$ and $300^{\circ} \mathrm{C}$, respectively) in the form of split ratio 1:30. The column temperature 
was adjusted and scanned from $40^{\circ} \mathrm{C}$ to $240^{\circ} \mathrm{C}\left(4^{\circ} \mathrm{C} / \mathrm{min}\right) .1 \mu \mathrm{l}$ of the diluted samples (v/v) (1/100 in heptane) were injected manually with a microsyringe.

GC-MS of three cultivars of cardamom, i.e., Sawney, Seremna, and Varlangy was carried out using Hewlett Packard G 1800C Series II GCD, GC-MS system assembled with HP-5MS column $(0.25 \mu \mathrm{m}$ film thickness and $30 \mathrm{~m} \times 0.25 \mathrm{~mm}$ ) ramping the temperature from $40^{\circ} \mathrm{C}$ to $260^{\circ} \mathrm{C}$ was operated between 40 and $450 \mathrm{~m} / \mathrm{z}$ and mass detector (Ionization energy: $70 \mathrm{eV}$ ). The components of essential oil extracted from the Sawney, Seremna, and Varlangy were identified by comparison of their retention indices and mass spectra with standard libraries (16; Wiley6; 1989 and NIST02 2008).

\section{Microorganisms, media, culture, and growth conditions}

Bacterial strains, Staphylococcus aureus MTCC-902, Bacillus subtilis MTCC-736, Klebsiella pneumoniae (MTCC-432), and Escherichia coli MTCC-443 and fungus strains, Candida albicans MTCC-183 and Aspergillus niger MTCC-1344 strains were used for this study to check the oil properties against them. Nutrient broth, Mueller-Hinton agar (MHA), and Sabouraud's dextrose agar (SDA) (HiMedia Laboratories) have been used for the bacterial and fungal growth followed by the standard protocols [17].

The bacteria were cultured at $37^{\circ} \mathrm{C}$ on MHA medium and incubated overnight to check its growth in pure culture. Similarly, the fungi were also cultured in SDA medium at $37^{\circ} \mathrm{C}$ to further check the fungal hypha growth. To prepare the bacterial and fungal inoculums, the overnight culture of bacteria and fungi was diluted, i.e., $10^{8} \mathrm{CFU} / \mathrm{ml}(0.5$ of McFarland) for bacterial and $10^{7} \mathrm{CFU} / \mathrm{ml}$ for the fungal spores to validate the oil efficiency against these microorganisms. $100 \mu \mathrm{l}$ inoculum was obtained from the secondary culture of microbes (bacterial and fungal) where spread under sterile condition in laminar hood on MHA and SDA basal media over the entire surface of the Petri plates.

\section{Antimicrobial screening of essential oil}

All three essential oils extracted from $A$. subulatum fruit samples were tested for antimicrobial activity using the well diffusion method [18]. The extracted oil $(20 \mathrm{mg} / \mathrm{ml}$ ) of each cultivar of A. subulatum (Sawney, Seremna, and Varlangy) was prepared using $10 \%$ dimethyl sulfoxide (DMSO, SigmaAldrich) solution and tested against the bacterium S. aureus and B. subtilis, $K$. pneumoniae, and E. coli and fungus $C$. albicans and A. niger strains. The antimicrobial activities of the samples were initially evaluated by modifying agar well diffusion assay. Wells $(6 \mathrm{~mm})$ of each plate were filled with $15 \mu \mathrm{l}$ of samples and incubate the plates for $24 \mathrm{~h}$ at $37^{\circ} \mathrm{C}$; bacteria, $48 \mathrm{~h}$ at $37^{\circ} \mathrm{C}$; yeast, and 7 days at $28^{\circ} \mathrm{C}$ for fungi were observed. Gentamicin (GEN-10 $\mu \mathrm{g} / \mathrm{ml}$ ) and 5-fluorocytosine $(5 \mathrm{FC}, 10 \mu \mathrm{g} / \mathrm{ml}$ ) were used as a positive control; similarly, $10 \%$ DMSO was used as a negative control. The experiments were repeated thrice, i.e., triplicate manner. The minimum inhibitory concentration (MIC) and minimum bacteriostatic concentration (MBC) were performed using the agar dilution method [19]. Six different dilutions $(20,10,5,2.5 .1 .25$, and $0.625 \mathrm{mg} / \mathrm{ml})$ were prepared and diluted solution (1 ml) of each cultivar oils was separately mixed to $19 \mathrm{ml}$ of MHA hot solution and poured on the sterile Petri plates. After solidification of MHA media, $1 \mathrm{ml}$ inoculum of each microbe was spread on sterile plates with oil and inoculated at $37^{\circ} \mathrm{C}$ for further observations in terms of antimicrobial activity. For the MIC, the visible growth was observed after $24 \mathrm{~h}$ of incubation and for the MBC, visible growth after 5 days of incubation. Similarly, MIC for fungistatic and MIC fungicide (MICF) was observed after incubation for 3 weeks at room temperature.

\section{RESULTS AND DISCUSSION}

\section{Percent oil recovery $A$. subulatum cultivars}

Collected cultivars from Sikkim have shown the diverse percentage content of the essential oils Table 1 . The results of the present study were shown that Seremna has a higher percentage $(2.7 \pm 0.10)$ of essential oil than other cultivars; Varlangy $(2.5 \pm 0.15)$ and Sawney $(1.7 \pm 0.20)$.

\section{Identification of active metabolites in A. subulatum cultivars}

The active chemical compositions of each cultivar oil are presented in Table 2.25 active compounds were identified in the Seremna oil ( $96.49 \%$ of total oil), while 25 and 27 compounds were identified in Varlangy and Sawney, respectively. The monoterpene, 1, 8-cineole is recorded highest metabolites in all the cultivars (Seremna, 72.5\%; Sawney, 61.83\%; and Varlangy, 56.89\%). A total of six major components were identified, including 1, 8-cineole and these compounds were limonene, D-nerolidol, $\alpha$-terpineol, $\beta$-pinene, and $\alpha$-pinene also identified in the present finding (Fig. 1).

In this study, we have observed that the several similar components reported in the essential oil of Nepal A. subulatum (1, 8-cineole, alpha-pinene, beta-pinene, alpha-terpineol, etc.) where, 1,8-cineole $(60.8 \%)$ has also been reported as the main components [20]. Joshi et al. studied on the six different cultivars collected from different altitudes of other regions than Sikkim, i.e., Himachal Pradesh, showed that 1,8-cineole $(50.55 \% \pm 1.87 \%-60.46 \% \pm 3.50 \%)$ was the main active constituents of $A$. subulatum essential oils. The percentage of the composition of essential oil is varying due to geographical region and its altitude. In the present study, three cultivars were cultivated in different geographical conditions, Seremna is highly cultivated at low altitude $(<900 \mathrm{~m})$, Sawney is cultivated at middle altitude (700-1500 m), while Varlangy is cultivated at high altitude ( $>1500 \mathrm{~m})$ [21]. In our findings, we have also analyzed that 1,8-cineole (eucalyptol) is main compounds of oil and the percentage varies cultivar to cultivar as well as altitude to altitude. This study is also supported by other groups $[22,23]$. The concentration and

Table 1: Percentage yield of oils of the selected cultivars

\begin{tabular}{ll}
\hline Cultivars & Percentage yield \\
\hline Varlangy & $2.5 \pm 0.15$ \\
Seremna & $2.7 \pm 0.10$ \\
Sawney & $1.7 \pm 0.20$ \\
\hline
\end{tabular}

$\mathrm{n}=3$, mean \pm SD. SD: Standard deviation

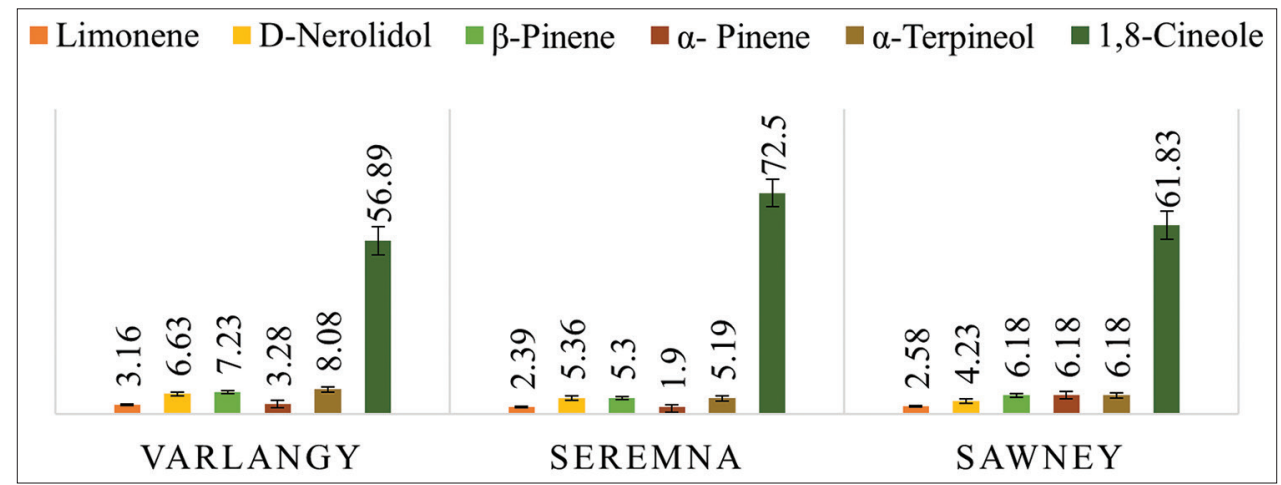

Fig. 1: Major compounds found in the essential oils of Amomum subulatum cultivars 
the percentage of the other components ( $\alpha$-pinene, $\beta$-pinene, terpineol, nerolidol, and limonene) were different from the previous reports [24]. This study is the $1^{\text {st }}$ time reported the chemical composition of Seremna and it was found higher than the other selected cultivars.

\section{Antimicrobial activity}

The inhibition zone of different essential oils against selected pathogens is shown in Table 3. Oil of Seremna was shown the good inhibition zones $(7.5 \pm 1.23-24.28 \pm 0.95 \mathrm{~mm})$ against all the microorganisms except
B. subtilis. The range of inhibition zones of the Varlangy oil was $9.41 \pm$ $0.94-14.25 \pm 1.26 \mathrm{~mm}$ and Sawney oil was between $10.72 \pm 0.96$ and $18.49 \pm 1.43 \mathrm{~mm}$, low against Gram-negative bacteria (K. pneumoniae) but high against Gram-positive bacteria ( $S$. aureus). The MIC and MBC values of all essential oils were reported against bacteria in Table 4 . The MIC and MICF values of all essential oils were reported against fungal strains in Table 5 . The MIC range of Varlangy oil was $2.5-5 \mathrm{mg} / \mathrm{ml}$, Seremna oil was $1.25-2.5 \mathrm{mg} / \mathrm{ml}$, and Sawney oil was $1.25-5 \mathrm{mg} / \mathrm{ml}$ for selected fungal strains.

Table 2: Chemical composition of the essential oils obtained from fruits of different cultivars of Amomum subulatum

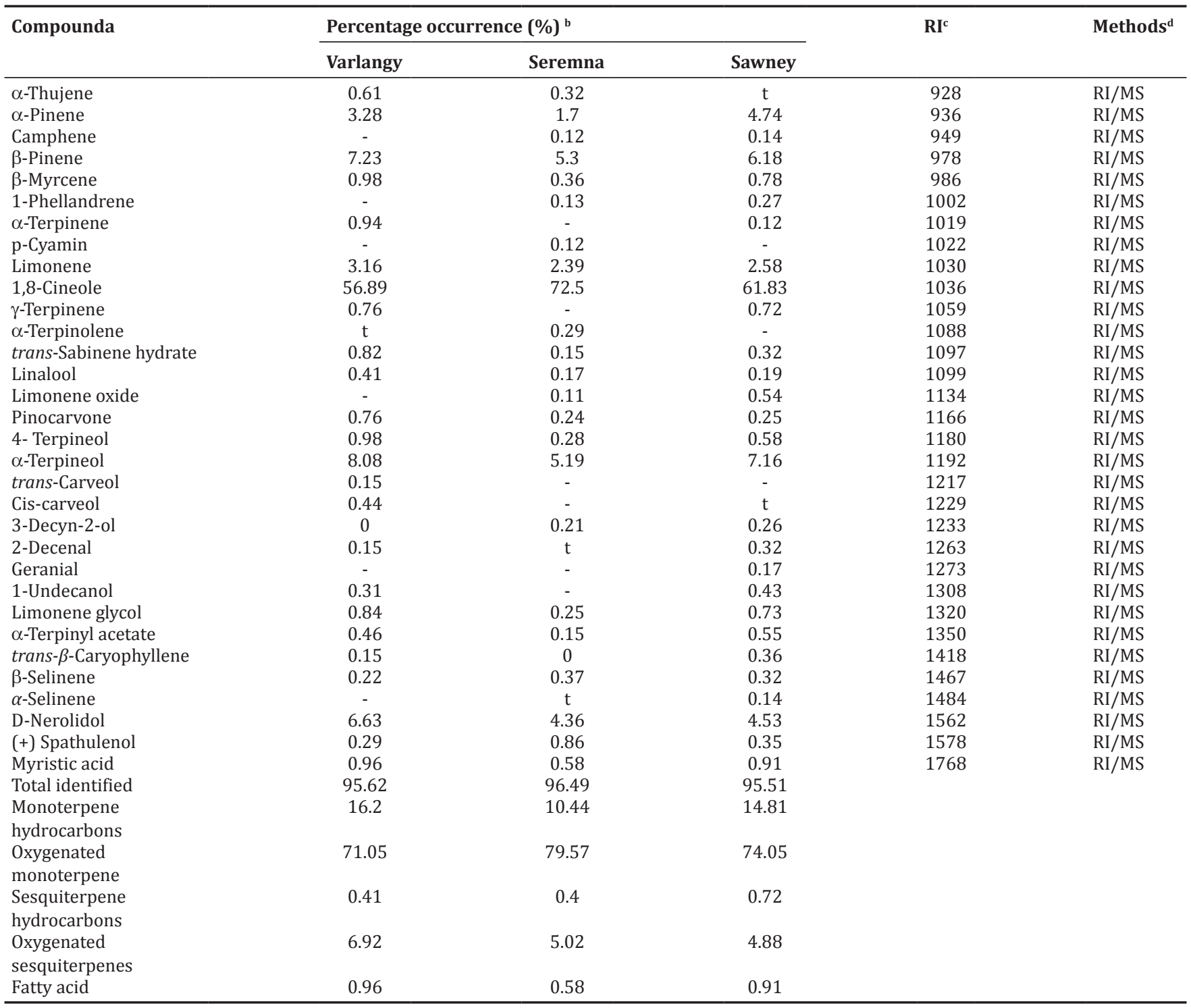

${ }^{\mathrm{a}}$ Compounds were recorded to the elution time from a column (HP-5 MS), ${ }^{\mathrm{b}}$ Percentage peak area (\%) was linked to total identified compounds by GC/MS, ${ }^{\mathrm{C}} \mathrm{RI}$ on HP-5 MS column using the homologous series of n-alkane (C8-C28), ${ }^{\mathrm{d}} \mathrm{RI}$ and mass spectra used, t: Less than $0.1 \%$, -: Not identified. GC/MS: Gas chromatography/mass spectrometry, RI: Retention indices

Table 3: Antimicrobial activity (zone of inhibition, mm) of essential oils of different cultivars of Amomum subulatum

\begin{tabular}{llll}
\hline Microorganisms & Varlangy & Seremna & Sawney \\
\hline Escherichia coli & NI & $7.5 \pm 1.23$ & NI \\
Bacillus subtilis & NI & NI & NI \\
Klebsiella pneumoniae & $9.41 \pm 0.94$ & $12.54 \pm 1.25$ & $10.72 \pm 0.96$ \\
Staphylococcus aureus & $11.26 \pm 0.95$ & $17.15 \pm 0.97$ & $15.3 \pm 1.64$ \\
Candida albicans & $14.25 \pm 1.26$ & $24.28 \pm 0.95$ & $18.49 \pm 1.43$ \\
Aspergillus niger & $10.05 \pm 1.25$ & $14.72 \pm 0.96$ & $12.06 \pm 1.25(\mathrm{GEM})$ \\
\hline
\end{tabular}

Values are expressed as mean \pm SD. ZI: Zone of inhibition, millimeter, NI: No inhibition, GEM: Gentamycin, positive control for antibacterial, 5FC: 5-fluorocytosine, positive control for antifungal, SD: Standard deviation 
Table 4: Determination of MIC and MBC $(\mathrm{mg} / \mathrm{ml})$ values of the essential oils of different cultivars of Amomum subulatum

\begin{tabular}{lllllllll}
\hline \multirow{2}{*}{ Bacterial strain } & \multicolumn{2}{l}{ Varlangy oil } & & \multicolumn{2}{c}{ Seremna oil } & & \multicolumn{2}{c}{ Sawney oil } \\
\cline { 2 - 3 } & MIC & MBC & & MIC & MBC & & MIC & MBC \\
\hline Escherichia coli & ND & ND & & 10 & ND & & ND & ND \\
Klebsiella pneumoniae & 5 & $<10$ & & 2.5 & 5 & & 5 & 5 \\
Staphylococcus aureus & 5 & $<10$ & & 2.5 & 5 & & 2.5 & 10 \\
\hline
\end{tabular}

ND: Did not study, MIC: Minimum inhibitory concentrations,

MBC: Minimal bactericidal concentration

Table 5: Determination of minimum inhibitory concentrations and minimum inhibitory concentration fungicide $(\mathrm{mg} / \mathrm{ml})$ values of the essential oils of different cultivars of Amomum subulatum

\begin{tabular}{lllllllll}
\hline \multirow{2}{*}{ Fungi } & \multicolumn{2}{l}{ Varlangy oil } & & \multicolumn{2}{c}{ Seremna oil } & & \multicolumn{2}{c}{ Sawney oil } \\
\cline { 2 - 3 } & MIC & MICF & & MIC & MICF & & MIC & MICF \\
\hline Candida albicans & 2.5 & 5 & & 1.25 & 2.5 & & 1.25 & 5 \\
Aspergillus niger & 5 & $<10$ & & 2.5 & 5 & & 5 & 10 \\
\hline
\end{tabular}

MICF: Minimum inhibitory concentration fungicide,

MIC: Minimum inhibitory concentration

Values are expressed as mean \pm standard deviation, Zone of inhibition, millimeter, no inhibition, gentamycin (GEM, Positive control) for antibacterial, and 5-fluorocytosine (5FC, positive control) for antifungal.

The antimicrobial study of oil of Seremna has shown high efficacy against Gram-positive bacteria in comparison to Sawney and Varlangy. The oils of all cultivars were shown a good inhibitory effect against fungal strains which is supported by previously reported studies that the plant parts which have major 1,8-cineole content in the essential oil showed good antibacterial and antifungal activities $[25,26]$. Oxygenated monoterpene, 1,8-cineole is a non-toxicants be used for the antimicrobial activity [27]. In addition to 1,8-cineole, the other compounds such as $\alpha$-terpineol, $\beta$-pinene, $\alpha$-pinene, D-nerolidol, and limonene are also contributing in the antimicrobial activity. Seremna essential oil showed the potential bactericidal action against the used

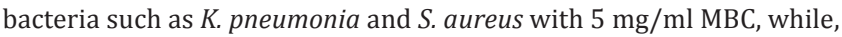
MBC of Sawney oil reached to $10 \mathrm{mg} / \mathrm{ml}$ and Varlangy reached to more than $10 \mathrm{mg} / \mathrm{ml}$ and these oils were less sensitive against both Gramnegative (K. pneumonia) and Gram-positive strains (S. aureus) strains. The present study showed that essential oil of $A$. subulatum was highly active against Gram-positive bacteria and among all selected and among all selected cultivars, Seremna oil was shown comparatively better antibacterial effects than Sawney and Varlangy may be due to the high percentage of the principal compound (1,8-cineole). Seremna oil showed potentially highest fungicide activity against selected fungus (C. albicans and A. niger) with MICF of $2.5 \mathrm{mg} / \mathrm{ml}$ and $5 \mathrm{mg} /$ $\mathrm{ml}$ for C. albicans and A. niger, respectively, while MICF of Sawney oil was $5 \mathrm{mg} / \mathrm{ml}$ and $10 \mathrm{mg} / \mathrm{ml}$ for C. albicans and A. niger, respectively. The essential oil of Varlangy was found to be less sensitive against A. niger and its MICF value reached to $10 \mathrm{mg} / \mathrm{ml}$. In the previous studies, investigators have reported that Gram-positive bacterial are more sensitive to volatile oils when compared to the Gram negative $[25,28]$. The plants contain 1,8-cineole as a major content showed good antimicrobial activities against gram-positive bacterial and fungal strains [29]. The antibacterial activity of $A$. subulatum essential oil might be due to the components such as 1,8-cineole, limonene, D-nerolidol, $\beta$-pinene, $\alpha$-pinene, and $\alpha$-terpineol $[30,31]$.

\section{CONCLUSION}

GC-MS study of essential oil of fruits of three different $A$. subulatum cultivars reported 1,8-cineole as the major constituents in all the cultivars. Of the six tested microorganisms, the essential oil of Seremna was found to be active against K. pneumoniae, E. coli, C. albicans, and
A. niger at concentrations ranging from 1.25 to $2.5 \mathrm{mg} / \mathrm{ml}$. The highest antimicrobial activity of Seremna oil may be due to the presence of high content of 1,8-cineole.

\section{ACKNOWLEDGMENT}

We acknowledge Mr. BA Gudade, Scientist B, Agronomy, ICRI, RRS spice board, Tadong, Gangtok, Sikkim (India), for providing us three authenticated cultivars of A. subulatum and Dr. Raeesh and Dr. Rizwan, Department of Pharmacy, King Saud University, Riyadh, for technical assistance of antimicrobials and GC-MS analysis

\section{AUTHORS' CONTRIBUTIONS}

Alam A designed the study project, performed experiments, wrote whole manuscript, and involved in throughout manuscript editing and finalization. Majumdar RS guide and approved the designed project helped in throughout project work. Alam P contributed in manuscript editing and finalization according to journal.

\section{CONFLICTS OF INTEREST}

Authors declared no conflicts of interest.

\section{REFERENCES}

1. Gautam N, Bhattarai RR, Khanal BK, Oli PP. Technology, chemistry and bioactive properties of large cardamom (Amomum subulatum Roxb.): An overview. Int J Appl Sci Biotechnol 2016;4:139-49.

2. Lim TK. Edible Medicinal and Non-Medicinal Plants: Volume 3 Fruits. Vol. 5. New York: Dordrecht Netherlands: Springer; 2013

3. Joshi R, Sharma P, Sharma V, Prasad R, Sud RK, Gulati A, et al. Analysis of the essential oil of large cardamom (Amomum subulatum Roxb.) growing in different agro-climatic zones of Himachal Pradesh, India. J Sci Food Agric 2013;93:1303-9.

4. Nybe EV, Raj NM, Peter KV. Spices. In: Peter KV, editor Horticulture Science Series. Vol. 5. New Delhi: New India Publishing Agency; 2007. p. 67

5. Singh KR, Basudha C, Ningombam A, Punitha P, Singh TB, Singh IM, et al. Training Manual on Entrepreneurship and Skill Development on Market Driven Production and Processing of High Value Crops of NEH Region. Publication No. RCM(TM). Lamphelpat, Imphal: ICAR Research Complex for NEH Region, Manipur Centre; 2017.

6. Gurudutt KN, Naik JP, Srinivas P, Ravindranath B. Volatile constituents of large cardamom (Amomum subulatum Roxb). Flavour Fragr J 1996;11:7-9.

7. Agnihotri S, Wakode S. Antimicrobial activity of essential oil and various extracts of fruits of greater cardamom. Indian J Pharm Sci 2010;72:657-9.

8. Sabulal B, Dan M, Pradeep NS, Valsamn RK, George V. Composition and antimicrobial activity of essential oil from fruits of Amomum subulatum. Acta Pharm 2006;56:473-80.

9. Bairwa G, Jasuja N, Joshi S. Lipid lowering and antioxidant effects of Amomum subulatum seeds (Family Zingiberaceae) in cholesterol fed rabbits. Arch Phytopathol Plant Prot 2011;44:1425-31.

10. Hsaine S, Charof R, Ounine K. Evaluation of antibacterial activity AF essential oil of Cinnamomum zeylanicum, Eugenia caryophyllata, and Rosmarinus officinalis against Streptococcus oralis. Asian J Pharm Clin Res 2009;5:411-3

11. Aggarwal SG, Goyal S. Comparative analysis of antimicrobial activity of essential oil of Ocimum kilimandscharicum. Asian J Pharm Clin Res 2012:5:53-5

12. Rout PK, Sahoo D, Jena KS, Rao YR. Analysis of the oil of large cardamom (Amomum subulatum Roxb.) growing in Sikkim. J Essent Oil Res 2003;15:265-6.

13. Kaskoos RA, Mir SR, Kapoor R, Ali M. Essential oil composition of fruits of Amomum subulatum Roxb. J Essent Oil Bearing Plants 2008;11:184-7.

14. Naveed R, Hussain I, Tawab A, Tariq M, Rahman M, Hameed S, et al. Antimicrobial activity of the bioactive components of essential oils from Pakistani spices against Salmonella and other multi-drug resistant bacteria. BMC Complement Altern Med 2013;13:265

15. Amaral RR, Fernandes CP, Caramel OP, Tietbohl LA, Santos MG, Carvalho JC, et al. Essential oils from fruits with different colors and leaves of Neomitranthes obscura (DC.) N. Silveira: An endemic species from Brazilian Atlantic forest. Biomed Res Int 2013;2013:723181. 
16. Alam P, Kamaluddin, Khan MA, Mohammad A, Khan R, Abdin MZ. Enhanced artemisinin accumulation and metabolic profiling of transgenic Artemisia anпиа L. plants over-expressing by rate-limiting enzymes from isoprenoid pathway. J Plant Interac 2014;9:655-65.

17. Kumar KN, Saraswathy A, Amerjothy S, Ravishankar B. Antimicrobial potential of Helicanthus elastica (Desr.) Danser a less explored Indian mistletoe growing on mango trees. J Tradit Complement Med 2014;4:258-62.

18. El-Kalamouni C, Venskutonis PR, Zebib B, Merah O, Raynaud C, Talou T, et al. Antioxidant and antimicrobial activities of the essential oil of Achillea millefolium L. Grown in France. Medicines (Basel) 2017;4:e30.

19. Djihane B, Wafa N, Elkhamssa S, Pedro HJ, Maria AE, Mihoub ZM, et al. Chemical constituents of Helichrysum italicum (Roth) G. Don essential oil and their antimicrobial activity against gram-positive and gram-negative bacteria, filamentous fungi and Candida albicans. Saudi Pharm J 2017;25:780-7.

20. Satyal P, Dosoky NS, Kincer BL, Setzer WN. Chemical compositions and biological activities of Amomum subulatum essential oils from Nepal. Nat Prod Commun 2012;7:1233-6.

21. Negi BK, Joshi RK, Pandey A. Status of large cardamom (Amomum subulatum roxb.) Farming systems in the changing scenario of modern economics of Sikkim, Himalaya. Glob J Biochem Biotechnol 2018;7:189-99.

22. Noumi E, Snoussi M, Alreshidi MM, Rekha PD, Saptami K, Caputo L, et al. Chemical and biological evaluation of essential oils from cardamom species. Molecules 2018;23:e2818.

23. Singh A, Sharma S, Singh S, Bond J, Rustagi A. Evaluation of antibacterial properties of essential oils from clove and Eucalyptus. Asian J Pharm Clin Res 2014;7:291-4.

24. Vijayan AK, Leela NK, Dhanalakshmi M, Akshitha HJ, Rahul R, Utpala $\mathrm{P}$, et al. Volatile oil composition of four popular varieties of large cardamom (Amomum subulatum Roxb.). J Spices Aromatic Crop 2017;26:37-43.

25. Safaei-Ghomi J, Ahd AA. Antimicrobial and antifungal properties of the essential oil and methanol extracts of Eucalyptus largiflorens and Eucalyptus intertexta. Pharmacogn Mag 2010;6:172-5.

26. Li L, Li ZW, Yin ZQ, Wei Q, Jia RY, Zhou LJ, et al. Antibacterial activity of leaf essential oil and its constituents from Cinnamomum longepaniculatum. Int J Clin Exp Med 2014;7:1721-7.

27. Simșek M, Duman R. Investigation of effect of 1, 8-cineole on antimicrobial activity of chlorhexidine gluconate. Pharmacognosy Res 2017;9:234-7.

28. Trombetta D, Castelli F, Sarpietro MG, Venuti V, Cristani M, Daniele C, et al. Mechanisms of antibacterial action of three monoterpenes. Antimicrob Agents Chemother 2006;49:2474-8

29. Bachir RG, Benali M. Antibacterial activity of the essential oils from the leaves of Eucalyptus globulus against Escherichia coli and Staphylococcus aureus. Asian Pac J Trop Biomed 2012;2:739-42.

30. Braca A, Siciliano T, D'Arrigo M, Germanò MP. Chemical composition and antimicrobial activity of Momordica charantia seed essential oil. Fitoterapia 2008;79:123-5.

31. Nezhad FM, Zeigham H, Mota A, Sattari M, Yadegar A. Antibacterial activity of Eucalyptus extracts on methicillin resistance Staphylococcus aureus. Res J Biol Sci 2009;4:905-8. 